\title{
Covid-19 Impact on Divorce Case Using Sentiment Analysis
}

\author{
Agung Handayanto' ${ }^{1}$ Padmi Dhyah Yulianti², Khoirya Latifah ${ }^{3 *}$ \\ ${ }^{1,3}$ Informatika, Fakultas Teknik dan Informaka, Universitas PGRI Semarang \\ ${ }^{2}$ Bimbingan dan Konseling, Fakultas Ilmu Pendidikan, Universitas PGRI Semarang \\ *corr-author: khoiriyalatifah@upgris.ac.id
}

\begin{abstract}
Covid-19 is a human tragedy. Covid 19 made the world experiences stress. The presence of covid 19 has made individuals and families face various threats such as physical, psychlogical, economic and educational. The study noted an increase in the divorce rate during the pandemic. Divorce will have a significant impact on both spouses and children. Therefore it is necessary to design a system to predict the divorce rate in the new normal, by determining the precision of the impcat of divorce in the post covid periode using polarity sentiment analysis methods as an effort to prevent divorce. The primary data collection methods is taken from the data of the applicat filling a lawsuite at the Semarang City Religious Court Office and using external data from social media (twitter API). Based on the results of research, the covid-19 pandemic has a negative impact on society of 0,8 .
\end{abstract}

Keywords: Divorce, Covid-19, Sentiment, Polarity.

\section{INTRODUCTION}

The Corona Virus first appeared in December 2019 in Wuhan City, Hubei Province, China (Fang-Guo et al., 2020). The Corona Virus can infect and cause respiratory diseases (Dutt, Jayesh; Ganatra, Bhavdeep; Suthar, Nilay ; Malek, Mohammedebrahim; Shuklad , Bhakti; Shukla , Krupali; Shukla , Karna ; Pandit , Shreya; Rachchh , Manish; Gokanif, 2021). It is not yet clear how this virus is transmitted. However, this virus causes minor to serious illnesses such as colds MERS and SARS. Suspect cases of Covid 19 are person: (a) with severe acute respiratory infection anf eith no other aetiology that fully expolains the clinical presentation abd a history of travel to or residence in China during 14 days prior to symptom inset, (b) a patient with any acute respiratory ilness and at least ine if the following durung the 14 days prior to symptom onset contact with a confirmed or probable case of SARS-CoV2- infection or worked in or attended a health care facility where patients with confirmed or probable SARS-CoV-2- 2 acute respiratory disease patients were being treated (Harapan et al., 2020).

The Virus is very dangerous because it can lead to death. The high risk when this death occurs, makes the world organization, WHO, on January 30, 2020, declared a global public health emergency. On February 11, 2020, WHO officially announced this new virus named COVID-19. Since its appearance in Wuhan China, Covid-19 has spread widely to 213 countries in the world, including Indonesia.

Based on data that researchers accessed on the WHO website on August 13, 2020, the number of COVID-19 cases worldwide has reached 20,162,474 with deaths of 737,414 people (https://covid19.who.int accessed 13 August 2020). In Indonesia itself, the government announced that the first time COVID-19 entered Indonesia is in March 2020. The spread of COVID-19 has also spread to almost every province in Indonesia. Data on 
COVID-19 cases in Indonesia based on data obtained by researchers from covid19.go.id (accessed on August 13, 2020) there were 132,816 confirmed, 87,558 recovered and 5,968 died.

The presence of the COVID-19 has changed all kinds of aspects of life from education (Liu and You-Hsien Lin, 2021), socio-economics (Kithiia et al., 2020), even family life (DU et al., 2020). The presence of COVID-19 brings a lot of physical and psychological stress. This condition has the potential to cause conflict between individuals. Conflicts with partners in marriage are not impossible in family life.

Many schools are closed, students are studying from home. This condition makes parents have more tasks because apart from having to take care of the household, they also have to work as teachers for their children. During the COVID-19 pandemic, parents have the role of guiding, guarding, educating, developing and supervising, and specifically parents must also maintain and ensure children live clean and healthy, accompany children to do school work, carry out joint activities at home, establish intense communication. with parents, playing with children, being a role model for children, supervising family members, providing for and meeting family needs, guiding and motivating children, providing education, maintaining religious values and promoting variety and innovation activities at home (Kurniati, Nur Alfaeni and Andriani, 2020)

In the field of work and the economy, many companies or businesses went bankrupt, causing a large labor reduction. The occurrence of a labor reduction will have an impact on families with reduced income. Studies say that low income often causes stress that comes from economic difficulties (Friedline, Chen and Morrow, 2021) [Social conditions and economic problems will affect the emotional stability of all family members. Conger, Conger \& Martin asserted that one of the family's mental health conditions is influenced by financial security conditions (Amato, 2001).

The presence of COVID-19 brings a lot of physical and psychological stress. This condition has the potential to cause conflict between individuals. Quarrels, conflicts with partners in marriage are not impossible in family life. This happens because of the adjustment of the two personalities.

The existence of conflicts that occur in marriage results in disharmony in the household. Parental discord and relationship dissatisfaction tend to extend into parent-child relationships, increasing conflict and chaos in the family environment more generally and posing additional risks for adult psychological and economic problems (Cui, Donnellan and Conger, 2007).

The existence of continuous conflict in a marriage can lead to divorce. Divorce is basically the end of a husband and wife relationship that is decided by law or religion (thalak) because there is no longer mutual interest, mutual trust and also no compatibility with one another, causing disharmony in the household (Ramadhani and Krisnani, 2019). Divorce is a turning point in family life (Lebow, 2020b)

Drodz, Saini \& Olesen predict around $10-20 \%$ of the population is in a process of conflict and/or disconnection which will make individual and relational problems more likely. Prasso informed that preliminary data from Tiongkok showed an increase in divorce cases during the self-quarantine period (Lebow, 2020a).

According the Ministry Of Religious Affairs Semarang that the number of divorce cases in Semarang City 2019 - 2020 as a figure 1 showed an increase in divorce cases : 


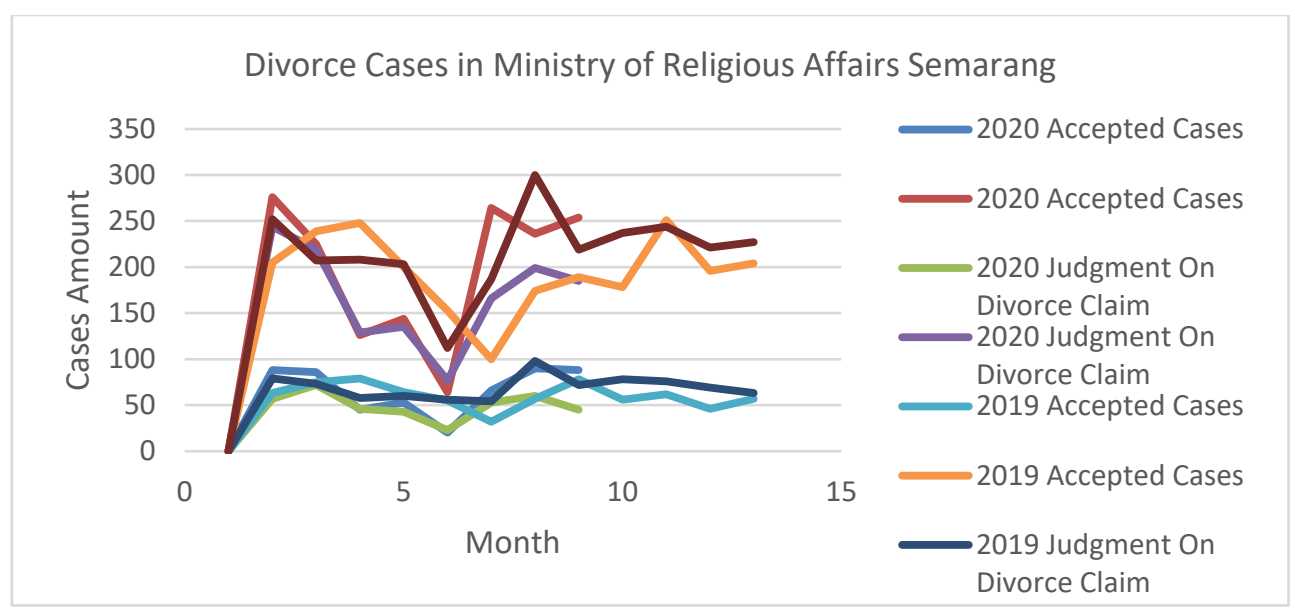

Figure 1. Research data processing 2020 Divorce cases in 2019-2020

Data obtained from the Semarang City Religious Court, in 2019, 550 cases were accepted for Talak divorce, and 1354 divorced cases. Meanwhile, 399 cases were decided for Talak divorce and 1354 divorced cases. Meanwhile, in 2020, case report data In the first instance received, data on 536 Talak divorces and 1589 divorced divorces were obtained. Meanwhile, in the reports that were decided at the Semarang religious court from January - August 2020, 399 cases were decided for divorce and 1354 divorced. The data every year can be seen as following Table 1 .

Table 1. Divorce data for January - August 2019 and 2020.

\begin{tabular}{|c|c|c|c|c|c|c|c|}
\hline \multicolumn{4}{|c|}{ Januari - Agustus 2019} & \multicolumn{4}{|c|}{ Januari - Agustus 2020} \\
\hline \multicolumn{2}{|c|}{ Acceptance Cases } & \multicolumn{2}{|c|}{$\begin{array}{c}\text { Judgment On } \\
\text { Divoce Claim } \\
\text { Cases }\end{array}$} & \multicolumn{2}{|c|}{ Acceptance Cases } & \multicolumn{2}{|c|}{$\begin{array}{c}\text { Judgment On } \\
\text { Divoce Claim } \\
\text { Cases }\end{array}$} \\
\hline $\begin{array}{l}\text { Thalak } \\
\text { Divorce }\end{array}$ & $\begin{array}{l}\text { Divorce } \\
\text { Lawsuit }\end{array}$ & $\begin{array}{l}\text { Thalak } \\
\text { Divorce }\end{array}$ & $\begin{array}{l}\text { Divorce } \\
\text { Lawsuit }\end{array}$ & $\begin{array}{l}\text { Thalak } \\
\text { Divorce }\end{array}$ & $\begin{array}{l}\text { Divorce } \\
\text { Lawsuit }\end{array}$ & $\begin{array}{l}\text { Thalak } \\
\text { Divorce }\end{array}$ & \\
\hline 559 & 1488 & 503 & 1310 & 536 & 1589 & 399 & 1354 \\
\hline
\end{tabular}

Based on Table 1, it is known that the number of reports is more in cases of divorce compared to Talak divorce cases. There is a difference of 101 cases in the reports received for 2019 and 2020. While in the reports, more filed for divorce. Thus, when compared to the previous year, during this pandemic there was a difference of 44 cases, especially for divorce cases compared to the previous year.

The occurrence of divorce will result in the individual bearing a new status, namely as a widower or widow. Research shows that divorced individuals are more susceptible to experiencing distress than those who are married or single (Zhou and Guo, 2021). This condition is certainly quite alarming because divorce will definitely have an impact on the divorced couple and the children of the couple.

Another study states that single mothers have a tendency to experience depression and anxiety in both men and women (Leopold, 2018). Meanwhile, parental divorce will have an impact or loss on children in several ways, such as dropouts, cognitive skills, welfare psychosocial and social relationships (Amato, 2001). Children will also tend to blame themselves, have a low focus of control and are less able to make adjustments (Bussell, 2008). The existence of temporary separation by parents is a type of family disorder that has a significant impact on young people Young people tend to have 
behavioral problems and hyperactivity (Garriga and Pennoni, 2020). Research on divorce has been carried out by Matondang. The results of the study mention that young age, economic factors, factors of not having children and husbands who are often rude are the causes of divorce (Matondang, 2014)

Based on a literature review regarding the impact of divorce during the COVID-19 pandemic, which can have a significant impact on spouses or children. This study aims to get sentiment about the impact of Covid-19 in the new normal. Sentiment analysis is a method for opinion mining which is part of text mining (Feldman and Sanger, 2006) Text mining is a field of data science that studies people's opinions, sentiment, evaluation, behavior and emotions towards entities such as products, services, individuals, organizations and their attributes (Lin, Wang and Zhou, 2016). Sentiment analysis is very useful to get more useful and useful information for an organization or a public opinion (Fathan Hidayatullah and Sn, 2014). That efforts to prevent divorce in the Semarang City area can be carried out, through various kinds of psychoeducational media through promotive and preventive efforts, it is hoped that this will help the government in creating a strong family.

\section{RESEARCH METHOD}

In this study, researchers used research methods to solve problems with configuration process sentiment analysis as a Figure 2 of the research flow.

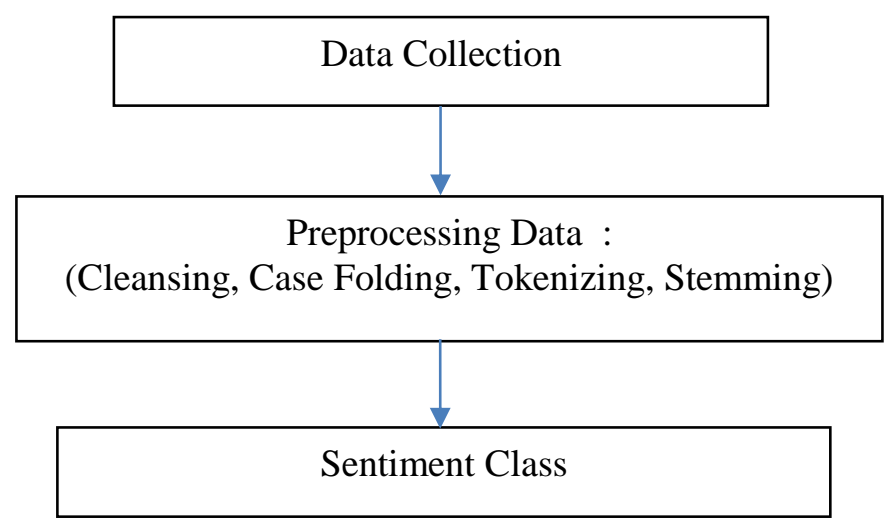

Figure 2. Research steps

a. Text Collection using twitterscapper data from the Twitter Streaming API based on the keyword "Impact of Pandemic" using Google Colab Python.

b. Preprocessing

After the data is collected, the next step is to preprocess the data by removing duplicates, and labeling the data. Making labels using annotations from a psychologist (Educational Psychology).

c. After removing the duplication of data and labeling by annotation, the next step is case folding, tokenizing and stemming (Tala, 2003). 


\section{RESULTS AND DISCUSSION}

This research was conducted using several stages, namely:

a. Dataset retrieval via twitter. The researcher's data set was collected in October 2020 January 2021. The data set was taken using the Streaming Twitter API using the search word "Impact of Covid-19". Twitter data crawl got 1790 data. The next stage is to clean the dataset because there are many duplicate tweets. After deleting duplicates, manually labeling or class tweets or annotations by a team of psychologist experts. The researcher gave a label (class) manually in the form of positive and negative sentiments.

b. Dataset cleaning. When the data retrieval process from Twitter has been carried out, then the dataset is preprocessed by cleaning the dataset. Preprocessing data with python: a) Delete duplicate data, b) Eliminate slang words, c) Stopword, d) Tokenizer, e) Delete url, f) Remove http, g) Convert to lower case, h) Delete unnecessary symbols, i) Removed additional white space and j) Delete RT

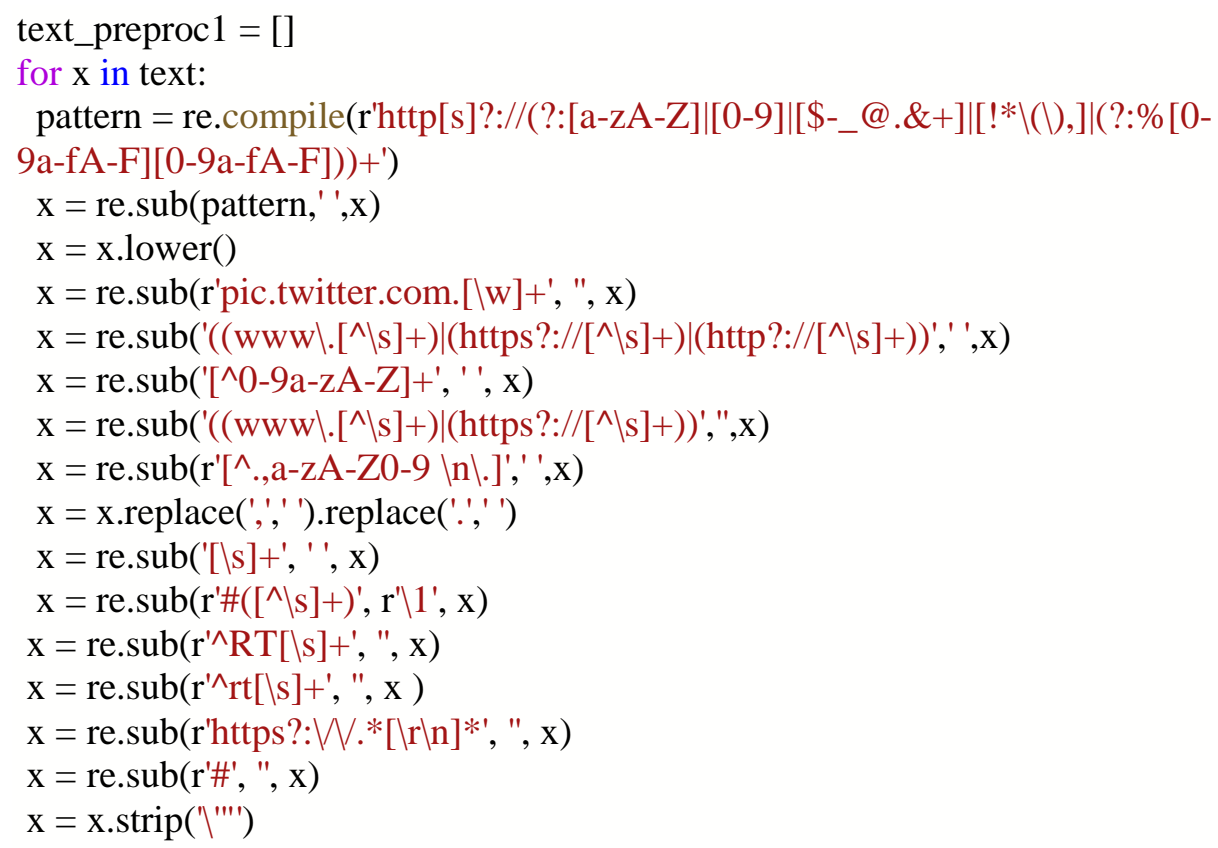

The results of data cleansing, stopword removal and tonenizing as shown in Figure 3 below still require further steps before giving sentiment classification. 


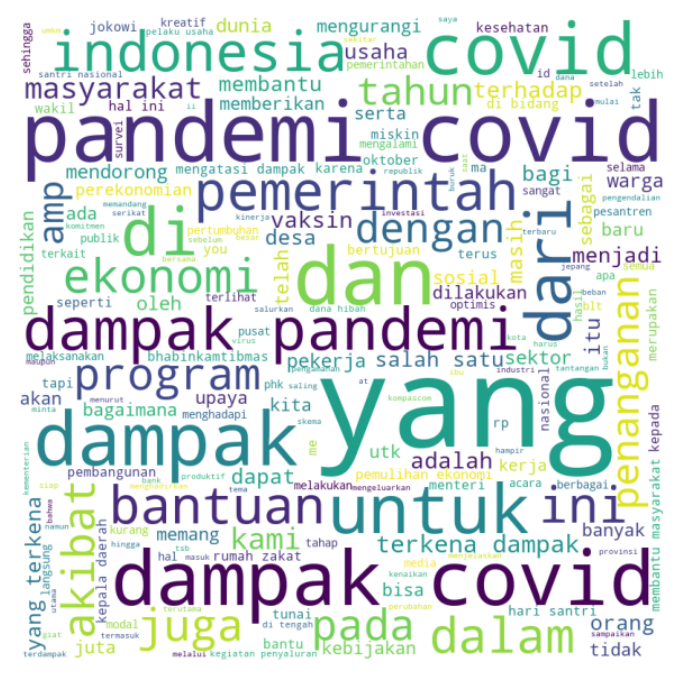

Figure 3. WordCloud preprocessing data

From the graph above, there are still some connecting words, prefixes and suffixes that are not clean.

c. Stemming uses literature. Stemming is a mapping process to get basic words from various forms. This process is done by removing prefixes, suffixes, insertions, or combinations of prefixes and suffixes contained in each word. Researchers use literature as a stemming tool because literature is suitable for Indonesian texts. Examples of stemming Indonesian Language can be described as Table 2 below :

Table 2. Examples of stemming Indonesian Language with literature

\begin{tabular}{ll}
\hline $\begin{array}{l}\text { Text before } \\
\text { stemming }\end{array}$ & Karena Pandemic Semua Orang \\
\hline Text after & Kardiam Dirumah \\
stemming & Diam Rumah \\
\hline
\end{tabular}

d. Stopword cleaning. After the dataset is stemming, the next step is to clean stop words using a library from literatur. An example of cleaning can be described as follows in Table 3.

Table 3. Example of cleaning stop words Indonesian language using literature

\begin{tabular}{ll}
\hline $\begin{array}{l}\text { Text before } \\
\text { stemming }\end{array}$ & $\begin{array}{l}\text { Karena Pandemic Semua Orang } \\
\text { Berdiam Dirumah }\end{array}$ \\
\hline $\begin{array}{l}\text { Text after } \\
\text { stemming }\end{array}$ & Pandemic Orang Diam Rumah \\
\hline
\end{tabular}


Based on the results of preprocessing and cleaning of duplicate data, 201 records were obtained with positive sentiments as many as 93 and negative sentiments as many as 108. The data is displayed by the researchers through the following chart as a Figure 4 below:

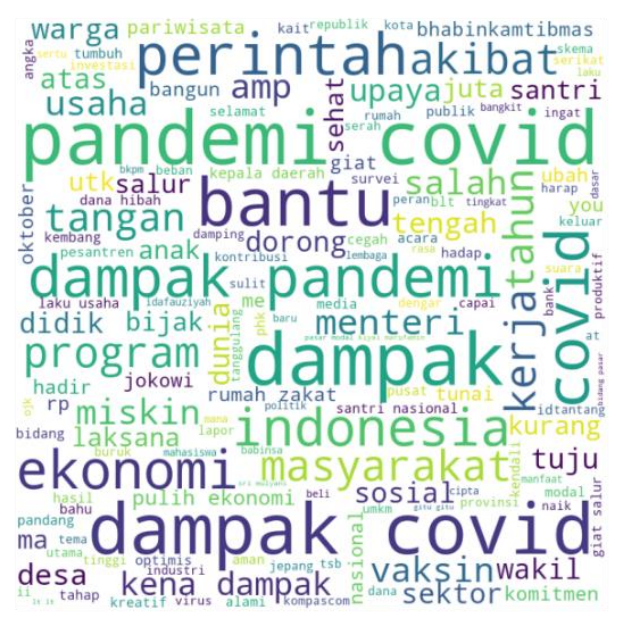

Figure 4. WordCloud

After stopword cleaning we can calculate the frequency of occurrence of the top 25 words as shown in the following graph: as a Figure 5.

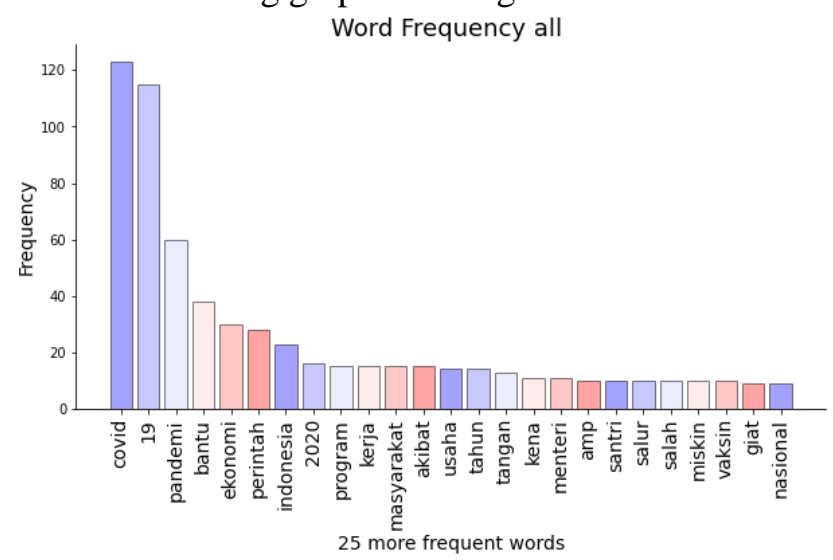

Figure 5. Word frequency

From the graph, the words that appear the most in the top 5 are the words covid, 19, pandemic, aid, and economy. To give sentiment, this research uses the Textblob library in Python. Giving sentiment to give a positive and negative classification. The provision of sentiment aims to find out how positive and negative sentiments are from some words that often appear on the twitter crawling data based on the keyword "Pandemic Impact".

e. Sentiment Analysis.The sentiment analysis method in this study uses a textblob in python, then calculates the average of positive and negative sentiments. Sentiment analysis is carried out using polarity sentiment analysis which is used to find out how much negative or positive public sentiment is on the impact of the pandemic. The following is the frequency of occurrence of the word. From the calculation results, the 
polarity of negative sentiment is 0.8 and positive sentiment is only 0.2 . Thus, from public tweets about the impact of the COVID-19 pandemic, the average public opinion about the impact of the COVID-19 pandemic is negative sentiment. This confirms that most of the community has a negative opinion about the impact of the pandemic. The polarity of the negative sentiment is shown in the following chart as Figure 6.

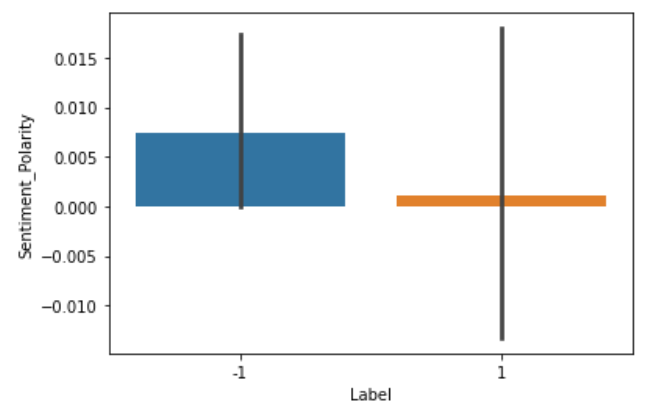

Figure 6. Polarity sentiment

Based on the results of the research, the public has a negative opinion regarding the impact of the COVID-19 pandemic, namely in the economic, social, poor and education sectors. This is in accordance with the results of empirical research that has been carried out by researchers that the COVID-19 pandemic has shown evidence of bringing significant psychological and social effects on the population. This impact is not only experienced by children but also to students and even to health workers.

In children, students and health workers are also susceptible to developing post-traumatic stress disorder, anxiety, depression and other symptoms (Saladino, Algeri and Auriemma, 2020). On the economic aspect, the COVID-19 pandemic has also greatly affected the global economy and financial markets.

Significantly, the decline in income experienced by everyone, the emergence of unemployment, and disruption in the transportation, services and manufacturing industries are one of the consequences that arise from disaster mitigation measures that have been implemented in many countries. This pandemic is unlikely to disappear quickly, thus international action needs to be taken through proactive measures that not only save lives but also protect economic prosperity (Pak et al., 2020).

\section{CONCLUSION}

Detection of negative public sentiment on the impact of the pandemic has a polarity of 0.8 so it can be concluded that the COVID-19 pandemic has a negative impact on society with a polarity value of 0.8 . This research method still has many shortcomings in order to get better features, the next step is the use of feature extraction other than TF-IDF, such as BOW, glove and so on.

\section{ACKNOWLEDGEMENT}

We would like to thank Lembaga Penelitian dan Pengabdian Masyarakat, Universitas PGRI Semarang. 


\section{REFERENCES}

Amato, P. R. (2001) '16Children of divorce in the 1990s: An update of the Amato and Keith (1991) meta-analysis', Journal of Family Psychology, 15(3), pp. 355-370. doi: 10.1037/0893-3200.15.3.355.

Bussell, D. A. (2008) 'Journal of Divorce \& A Pilot Study of African American Children' s Cognitive and Emotional Reactions to Parental Separation A Pilot Study of African American Children 's Cognitive and Emotional Reactions to Parental Separation', (February 2015), pp. 37-41. doi: 10.1300/J087v24n03.

Cui, M., Donnellan, M. B. and Conger, R. D. (2007) 'Reciprocal influences between parents' marital problems and adolescent internalizing and externalizing behavior.', Developmental Psychology. Cui, Ming: Department of Family and Child Sciences, Florida State University, 216 Sandels Building, Tallahassee, MDX, US, 32306, mcui@fsu.edu: American Psychological Association, pp. 1544-1552. doi: 10.1037/0012-1649.43.6.1544.

DU, Z. xiong et al. (2020) '6The short- and long-term impacts of the COVID-19 pandemic on family farms in China - Evidence from a survey of 2324 farms', Journal of Integrative Agriculture, 19(12), pp. 2877-2890. doi: 10.1016/S20953119(20)63390-1.

Dutt , Jayesh; Ganatra , Bhavdeep; Suthar, Nilay; Malek, Mohammedebrahim; Shuklad , Bhakti; Shukla , Krupali; Shukla , Karna; Pandit, Shreya; Rachchh , Manish; Gokanif, R. B. (2021) 'A randomized and comparative study to assess safety and efficacy of supplemental treatme t of a herbal formulation - Aayudh Advanc e comprising essential oils in patients with corona virus 2019 ( OV ID - 19 )', Contemporary Clinical Trials Communications, 22, pp. 1-7.

Fang-Guo, L. et al. (2020) 'Discussion on Etiology and Pathogenesis of Corona Virus Disease 2019 from "Cold-dampness and Insidious Dryness"', Digital Chinese Medicine, 3(1), pp. 50-54. doi: 10.1016/j.dcmed.2020.03.006.

Fathan Hidayatullah, A. and Sn, A. (2014) 'Analisis sentimen dan klasifikasi kategori terhadap tokoh publik pada twitter', in Seminar Nasional Informatika. Yogyakarta: UPN 'Veteran' Yogyakarta, pp. 115-122.

Feldman, R. and Sanger, J. (2006) The text mining handbook, The Text Mining Handbook. New York: United States of America by Cambridge University Press, New York. doi: $10.1017 / \mathrm{cbo} 9780511546914$.

Friedline, T., Chen, Z. and Morrow, S. P. (2021) '7Families' financial stress \& well-being: The importance of the economy and economic environments', Journal of Family and Economic Issues, 42(0123456789), pp. 34-51. doi: 10.1007/s10834-020-09694-9.

Garriga, A. and Pennoni, F. (2020) '18The causal effects of parental divorce and parental temporary separation on children's cognitive abilities and psychological well-being according to parental relationship quality', Social Indicators Research, (0123456789). doi: 10.1007/s11205-020-02428-2.

Harapan, H. et al. (2020) 'Since January 2020 Elsevier has created a COVID-19 resource centre with free information in English and Mandarin on the novel coronavirus COVID- 19. The COVID-19 resource centre is hosted on Elsevier Connect, the company' s public news and informatio', Journal of Infection and Public Health, 13(January), pp. 667-673. doi: 10.1016/j.jiph.2020.03.019.

Kithiia, J. et al. (2020) '4The socio-economic impacts of Covid-19 restrictions: Data from 
the coastal city of Mombasa, Kenya', Data in Brief, 33, p. 106317. doi: 10.1016/j.dib.2020.106317.

Kurniati, E., Nur Alfaeni, D. K. and Andriani, F. (2020) 'Analisis Peran Orang Tua dalam Mendampingi Anak di Masa Pandemi Covid-19’, Jurnal Obsesi : Jurnal Pendidikan Anak Usia Dini, 5(1), p. 241. doi: 10.31004/obsesi.v5i1.541.

Lebow, J. L. (2020a) '11Family in the age of COVID-19', Family Process, 59(2), pp. 309312. doi: 10.1111/famp.12543.

Lebow, J. L. (2020b) '12The challenges of COVID-19 for divorcing and post-divorce families', Family Process, 59(3), pp. 967-973. doi: 10.1111/famp.12574.

Leopold, T. (2018) '14Gender differences in the consequences of divorce: A study of multiple outcomes', Demography, 55(3), pp. 769-797. doi: 10.1007/s13524-0180667-6.

Lin, Y., Wang, X. and Zhou, A. (2016) Opinion spam detection, Opinion Analysis for Online Reviews. Morgan \& Claypool. doi: 10.1142/9789813100459_0007.

Listiowarni, I. and Dewi, N. P. (2020) 'Pemanfaatan Klasifikasi Soal Biologi Cognitive Domain Bloom's Taxonomy Menggunakan KNN Chi-Square Sebagai Penyusunan Naskah Soal', Digital Zone: Jurnal Teknologi Informasi Dan Komunikasi, 11(2), pp. 185-195.

Liu, C. H. and You-Hsien Lin, H. (2021) '3The impact of COVID-19 on medical education: Experiences from one medical university in Taiwan', Journal of the Formosan Medical Association, 120(9), pp. 1782-1784. doi: 10.1016/j.jfma.2021.02.016.

Matondang, A. (2014) 'Jurnal Ilmu Pemerintahan dan Sosial Politik UMA Faktor-faktor yang Mengakibatkan Perceraian dalam Perkawinan', Jurnal Ilmu Pemerintahan dan Sosial Politik, 2(2), pp. 141-150.

Pak, A. et al. (2020) 'Economic consequences of the COVID-19 outbreak: The need for epidemic preparedness', Frontiers in Public Health, 8(May), pp. 1-4. doi: 10.3389/fpubh.2020.00241.

Ramadhani, P. E. and Krisnani, H. (2019) '10Analisis dampak perceraian orang tua terhadap anak remaja', Focus: Jurnal Pekerjaan Sosial, 2(1), p. 109. doi: 10.24198/focus.v2i1.23126.

Saladino, V., Algeri, D. and Auriemma, V. (2020) 'The psychological and social impact of Covid-19: New perspectives of well-being', Frontiers in Psychology, 11(October). doi: 10.3389/fpsyg.2020.577684.

Tala, F. Z. (2003) A study of stemming effects on information retrieval in Bahasa Indonesia, M.Sc. Thesis, Appendix D. Amsterdam.

Zhou, M. and Guo, W. (2021) '13Subjective distress about COVID-19 and its social correlates: Empirical evidence from Hubei Province of China', Journal of Affective Disorders, 289(October 2020), pp. 46-54. doi: 10.1016/j.jad.2021.04.026. 